\title{
The Fire Ritual of the Iguvine Tables: Facing a Central Problem in the Study of Ritual Language
}

\section{Citation}

Nagy, Gregory. 2007. "The Fire Ritual of the Iguvine Tables: Facing a Central Problem in the Study of Ritual Language." Classical World 100 (2): 151-157. doi:10.1353/clw.2007.0017.

\section{Published Version}

doi:10.1353/clw.2007.0017

\section{Permanent link}

http://nrs.harvard.edu/urn-3:HUL.InstRepos:14531703

\section{Terms of Use}

This article was downloaded from Harvard University's DASH repository, and is made available under the terms and conditions applicable to Other Posted Material, as set forth at http:// nrs.harvard.edu/urn-3:HUL.InstRepos:dash.current.terms-of-use\#LAA

\section{Share Your Story}

The Harvard community has made this article openly available.

Please share how this access benefits you. Submit a story.

\section{Accessibility}




\section{The fire ritual of the Iguvine Tables: Facing a central problem in the study of ritual language}

[Originally published 2007 in Classical World 100:151-157, 10.1353/clw.2007.0017. Second edition, published online 2015.]

§1. Almost fifty years ago, I published a study of a fire ritual that we see described and in fact prescribed in the Iguvine Tables, a set of ancient sacred texts stemming from the Umbrian city of Iguvium. ${ }^{1}$ In the intervening years, I have often returned to this study in teaching-andlearning experiments that I have designed for analyzing the use of ritual language in traditional societies. Each return brought home to me the problems facing researchers, teachers, and students in dealing with ritual language. These problems led me to rethink, more than once, what I wrote in my original study, and I attempt here to formulate my cumulative rethinking. ${ }^{2}$ The central problem, in terms of my rethinking, is the opacity of such ritual language. This opacity, I argue, must not be mistaken for careless or muddled thinking: on the contrary, it is a vital aspect of ritual as expressed by the language of ritual. Ritual is opaque to the unauthorized-and it is meant to be so-whereas it is meant to be translucent to the authorized.

\footnotetext{
${ }^{1}$ The work to which I am referring is the fifth of six studies in Nagy 1974, "Six Studies of Sacral Vocabulary Relating to the Fireplace." The six studies concern the following forms:

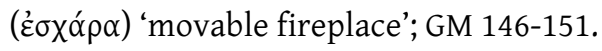

2. Latin āra 'altar'; GM 151-155

3. Latin altāria and adolēe; GM 155-160

4. Latin focus 'movable fireplace'; GM 160-164

5. Umbrian ahti- 'movable fireplace' and aso- 'movable fireplace'; GM 164-170

6. Hittite haš- 'beget', hašša- 'fireplace', haššu- 'king' GM 170-174.
}

${ }^{2}$ Even before I published the printed version of this article in 2007, I had published a rewritten version of the larger 1974 article in the still larger context of a comparative study of Greek myths and rituals, "The King and the Hearth: Six Studies of Sacral Vocabulary Relating to the Fireplace," chapter 6 in Nagy 1990b, Greek Mythology and Poetics. In referring to this 1990 version, I will hereafter use the abbreviation GM plus the relevant page-number.

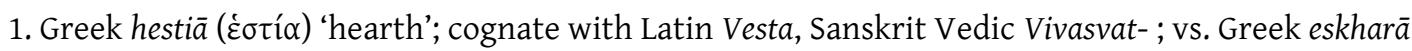


\$2. As we learn from the sacral language that describes and prescribes the sacred fire ritual of Iguvium in the Iguvine Tables, which is a text written for the 'Atiedian Brethren' of Iguvium, there is a special person who is authorized to perform this ritual. And there is an essential sacred object that is used to hold the sacred fire in the ritual. The word for this object is ahti, which is a central feature of the religious life of Iguvium.

§3. This word ahti can be traced back to an action-noun derived from an Umbrian verb that is cognate with the Latin verb agō, which I translate for the moment as 'act' or 'activate' or 'do'. In terms of its form, this action-noun is the equivalent of the Latin action-noun actio 'action', derived from the verb $a g \bar{o}^{3}$ The actual form that we see in Umbrian seems to have an added thematic vowel -o- , so that we may reconstruct ahti as *acti(o)- . In terms of its etymology, then, I view the noun ahti as ritual 'action' or 'activation' or 'doing' par excellence.

\$4. So much for the etymology of this Umbrian word ahti, which leads us to expect a meaning that matches the meaning of Latin actiō, that is, 'action'. But the meaning of Umbrian ahti, as used in the ritual language of the Iguvine Tables, is concrete rather than abstract. As I said earlier, ahti refers to the container of the fire used in the fire ritual. So the usage of this noun reveals a semantic specialization from abstract to concrete reference. Looking for parallel phenomena, we find comparable examples of semantic specialization in the case of English abstract nouns in -ing. In English, when -ing is added to the stem of a verb and produces an abstract noun, such a noun ordinarily refers to the action inherent in the verb, as in move $\rightarrow$ moving or carry $\rightarrow$ carrying or bring $\rightarrow>$ bringing. But there are cases of semantic

\footnotetext{
${ }^{3}$ At this point in the original article published in Classical World (Nagy 2007:152n3), I thanked Michael Weiss for showing me his then unpublished work on this word and on related words like aso-, to be discussed in what follows. The work was finally published in Weiss 2010.

${ }^{4}$ Weiss 2010:103n22 considers the possibility that *acti(o)- is derived directly from a ti-stem that would be the equivalent of Latin actiō. He also considers an alternative possibility: that *acti(o)- might be an iio-derivative from the equivalent of Latin actum. I prefer the first possibility.
} 
specialization where the abstract noun becomes a concrete noun referring to the result of the action, as in build $\rightarrow$ building or carve $\rightarrow$ carving or offer $\rightarrow>$ offering. And there are cases where the reference highlights not so much the result of the action but the means that achieve the result, as in cover $\rightarrow$ covering or kindle $\rightarrow$ kindling or set $\rightarrow>$ setting. Correspondingly, the Umbrian noun ahti, cognate with the Latin action-noun actiō 'action' as derived from agō in the sense of 'act' or 'activate' or 'do', designates the means that achieve the result of the 'action'the result of 'doing' what is done in the action. The result of the 'action' is the carrying of the sacrificial fire, and the Umbrian ahti is the container that is used for achieving this 'action'. That container is the equivalent of what is called in Latin a focus, which refers to a container of fire, a 'movable fireplace. ${ }^{5}$ In Romance languages, the derivatives of Latin focus become the generic word for 'fire', as in French feu, Spanish, fuego, Italian fuoco. ${ }^{6}$

\$5. Before I consider the ritual 'action' of carrying a container called the ahti, I offer a summary of a fire ritual that takes place in Iguvium. This ritual, as recorded in the Iguvine Tables (hereafter $=$ IT) of the Atiedian Brethren describes and prescribes the sequence of events as follows. I start here with the fact that pir 'fire' must be kindled on the way leading arven 'to the field' (IT III 11-12). The pir 'fire' must then be placed ase 'on the altar [asa]', which is vuke 'in the grove' (IT III 21-22). Then an animal sacrifice must be made iuvepatre 'to Jupiter' at the right side of the altar (IT III 22-23) on behalf of the following four entities:

fratrusper atiieries 'for the Atiedian Brethren'

ahtisper eikvasatis 'for the ahti-s eikvasatis

tutaper iiuvina 'for the people of Iguvium'

\footnotetext{
${ }^{5}$ GM 160-164.

${ }^{6} \mathrm{GM} 106$ on Italian fuoco prendere.
} 
trefiper iiuvina 'for the tribus of Iguvium'

§6. In the archaizing Latin text known nowadays as The Acts of the Arval Brethren, there are comparable formulas: there too we find mention of a prescribed sacrifice in luco 'in the grove', and it takes place in ara 'on an altar [ära]', and in foculo 'in a movable fireplace'. ' In Latin, the ära 'altar' is an immovable fireplace, by contrast with the focus or foculus, which is a movable fireplace. ${ }^{8}$ In other archaizing Latin contexts, we find the sacral expression pro aris focisque 'for the immovable and movable fireplaces', which is parallel to the Umbrian sacral expression ahtisper 'for the ahti- $\mathrm{s}$ '.

§7. Now I turn to another fire ritual of the Umbrian Iguvine Tables, as prescribed in two versions: one is written in the Latin alphabet (IT VIb 48-53), while the other is written in the "native" Umbrian alphabet (IT Ib 10-16). In what follows, I will analyze both versions, highlighting the fact that the version written in the Latin alphabet is marked by periphrasis of central elements of the ritual. For example, the noun ahti, regularly used in the version written in the Umbrian alphabet, is avoided and replaced by pufe pir entelust 'where the fire is placed'. Such ritualized periphrasis in referring to the ahti, the sacred container of the sacred pir 'fire', indicates the central importance of this object to the community.

§8. The Umbrian word pir 'fire' is cognate with the Greek word pür ( $\pi \tilde{v} \rho$ ) 'fire', as also with English fire. The attested Latin word for 'fire' is ignis, cognate with Vedic Sanskrit agni- 'fire'. Curiously, the cognate of Umbrian pir is not attested in Latin. At least, it is not attested as a simple noun. I propose, however, that it is in fact attested in the Latin verb pürgo 'purge, purify'. I agree with those who explain this form as *pūrigō, derived from the syntactical

\footnotetext{
${ }^{7}$ GM 165. In the Classical World article (Nagy 2007:153), "an immovable fireplace" is accidentally printed as "a movable fireplace."

${ }^{8}$ GM 160-163.

${ }^{9}$ GM 165-166.
} 
combination of *pūr with agō. ${ }^{10}$ The meaning of pürgō in the sense of 'purge, purify' can be explained in the sense of 'do fire': syntactically, * pūr 'fire' is the inner object of the verb agō here, while its outer object is whatever is 'purged' or 'purified' by the action of 'doing fire'. Similarly, Latin fümigō 'fumigate' can be explained as 'do smoke'; syntactically, fümus 'smoke' is the inner object of the verb ago here, while its outer object is whatever is fumigated by the action of 'doing smoke'. ${ }^{11}$ The same root that we see in the Latin noun fümus 'smoke' is found also in the Greek verb thuō 'sacrifice', which means etymologically 'do smoke'.

§9. I posit a semantic connection between the Latin verb pūrgō and the Umbrian noun ahti, which as we have seen can be explained as an action-noun referring to the sacred 'action' of 'doing' pir 'fire'. That sacred 'action' is still preserved in the fire ritual of Umbrian Iguvium.

\$10. In what follows, I reproduce the wording that describes and prescribes the central part of this ritual. Setting up two parallel columns, I place into the left-hand column the wording of the newer version written in the Latin alphabet (IT VIb 48-53), and I place into the right-hand column the wording of the older version written in the native Umbrian alphabet (IT Ib 10-16). From here on, though I will continue to transcribe in italics what is written in the Latin alphabet, I will begin to transcribe in boldface what is written in the "native" Umbrian alphabet. $^{12}$

\section{Iguvine Tables VIb 48-53 (Latin alphabet) vs. Ib 10-16 (Umbrian alphabet)}

\begin{tabular}{|l|l|}
\hline A) pone poplo afero heries & A) pune puplum aferum heries \\
\hline when he wishes to perform a & when you wish to perform a \\
\hline
\end{tabular}

\footnotetext{
${ }^{10}$ Thurneysen 1912-1913; see further GM 180.

${ }^{11} \mathrm{GM} 180$.

${ }^{12}$ The text of the wordings shown here follows the edition of Poultney 1959.
} 


\begin{tabular}{|l|l|}
\hline lustration of the people & lustration of the people \\
\hline B) avif aseriato etu & B) avef anzeriatu etu \\
\hline he shall go and observe the birds & go and observe the birds \\
\hline Ca) ape angla combifianšiust & C) pune kuvurtus \\
\hline when he has announced the angla & when you have returned \\
\hline Cb) perca arsmatiam anouihimu & \\
\hline he shall put on the perca arsmatia & D) krenkatrum hatu \\
\hline Da) cringatro hatu & have the krenkatrum \\
\hline he shall have the cringatro & in the ahti \\
\hline the fire [pir] is carried [ferar] to the & then pune pir entelus ahtimem \\
\hline he shall put it on his right shoulder & \\
\hline Ecapla] & \\
\hline E) pir endendu & \\
\hline whe shall place fire [pir] & \\
\hline
\end{tabular}




\begin{tabular}{|l|l|}
\hline sacrifice & \\
\hline Fb) ere fertu poe perca arsmatiam & \\
habiest & \\
\hline he shall carry [fertu] it, the one who perca arsmatia & \\
\hline $\begin{array}{l}\text { Fc) erihont aso destre onse fertu } \\
\text { on his right shoulder [onse] }\end{array}$ & \\
\hline the same shall carry [fertu] the aso & \\
\hline $\begin{array}{l}\text { Iguvium erucom prinuatur dur etuto } \\
\text { with him shall go two prinuati }\end{array}$ & Iguvium \\
\hline H) seso tote iiouine & \\
\hline $\begin{array}{l}\text { they shall have the perca ponisiater } \\
\text { G) ennom stiplatu parfa desua }\end{array}$ & \\
\hline then he shall pronounce a parfa-bird & then pronounce a parfa-bird on the \\
\hline
\end{tabular}


\$11. Here I offer a revised version of my earlier work on these wordings. ${ }^{13}$ I start with the expression poe perca arsmatiam habiest 'the one who has [habiest] the perca arsmatia' in section $\mathrm{Fb}$ at VIb 50. This expression is a periphrasis that we see being used here and elsewhere as well in the Iguvine Tables (VIb 53, 63; VIIa 46, 51) to designate an authorized priestly official whose title is arsfertur, as spelled in the Latin alphabet (VIa 2, 3, 8, 17; VIIb3), or arffertur, as spelled in the native Umbrian alphabet (Ib 41, IIa 16, Va 3,10, Vb 3, 5, 6). ${ }^{14}$ This form arsfertur / ařfertur is an agent-noun derived from the Umbrian equivalent of the Latin verb ferō in the sense of 'carry'. From here on, I refer to this official called arsfertur / arffertur simply as "Adfertor," which is a latinized equivalent of his Umbrian title. As we can see from all the contexts where he is mentioned in the Iguvine Tables, the Adfertor is the chief sacrificer in these texts. This sacral function of the Adfertor is relevant to the etymology of arsfertur / arffertur, derived as it is from the Umbrian equivalent of the Latin verb ferō in the sense of 'carry'. The Adfertor, as we are about to see, is the one who 'carries', that is, the one who shall carry the sacred fire.

\$12. I return to the wording of the description poe perca arsmatiam habiest 'the one who has [habiest] the perca arsmatia', which as I have already noted applies to the Adfertor in section $F b$ at VIb 50. At an earlier point in the left-hand column, in section Cb at VIb 49, the accusative perca arsmatiam is the direct object of the verb anouihimu, which can be translated as 'he shall put on', as we read in the wording perca arsmatiam anouihimu 'he shall put on the perca arsmatia'. So the man described in section $F b$ as the man who 'has' (habiest) the perca arsmatia as the mark of his status as chief sacrificer or Adfertor is instructed in section $C b$ to 'put it on' (anouihimu). This perca is a garment, as I will now argue.

\footnotetext{
${ }^{13}$ GM 167-170.

${ }^{14}$ In VI 3, the spelling is a cross between the Latin and the native Umbrian versions, arfertur.
} 
\$13. In section $D a$ at VIb 49, the Adfertor is instructed to have at hand what is definitely a garment, called a cringatro, as attested in the wording cringatro hatu 'he shall have [hatu] the cringatro'. This form cringatro in section $D a$ at VIb 49, written in the Latin alphabet, corresponds to krenkatrum in section $\underline{D}$ at $\mathrm{Ib} 11$, that is, in the parallel text written in the native Umbrian alphabet. The Umbrian noun cringatro / krenkatrum is comparable to the Latin nouns cinctus and cingulum, the etymology of which has to do with binding or girding. In the text written in the Latin alphabet, the cringatro that is mentioned in section $D a$ becomes in section $D b$ the implied direct object of a second occurrence of the verb anouihimu, meaning 'he shall put it on': so, here in section $D b$, the Adfertor is being instructed to put on the cringatro-putting it on his right shoulder, as we read in the wording destrame scapla anouihimu 'he shall put it on [anouihimu] his right shoulder'. In sections $D a$ and $D b$, then, we find that the status of the man who 'shall have' (hatu) a garment called the cringatro is correlated with the action of this man in 'putting it on' (anouihimu) his right shoulder (scapla). And there is a parallel correlation between the status and the action of the same man as he is further described in the text. In section $F b$, we see that Adfertor is actually the official holder of the perca arsmatia, which he officially 'has' (habiest). And, in section Cb, he has just been instructed to 'put it on' (anouihimu).

\$14. After it is specified in section Db that the Adfertor 'shall put on' (anouihimu) his right shoulder the cringatro, it is further specified in section $E$ that 'he shall place fire' (pir endendu). And then, as this fire 'is carried' (ferar) to the place of sacrifice in section $F a$, it is still further specified in section Fb that the person who 'shall carry' (fertu) this fire must be the Adfertor himself, that is, 'the one who has [habiest] the perca arsmatia'. Next, in section $F c$, we read that the Adfertor is instructed to carry an object called an aso on his right shoulder: erihont aso destre onse fertu 'the same [= the Adfertor] shall carry [fertu] the aso on his right shoulder [onse]'. 
\$15. In terms of my interpretation of the instructions written in the Latin alphabet, as I have just read through them from $A$ through $F$, the official known as the Adfertor must wear on his right shoulder a garment called the cringatro $(D b)$ and he must carry on that same right shoulder this object that I just highlighted, the aso $(F c)$. Also, the Adfertor must wear a garment called the perca arsmatia $(\mathrm{Cb})$, which is rightfully his to wear, since he is described periphrastically as poe perca arsmatiam habiest 'the one who has [habiest] the perca arsmatia' (Fb).

\$16. Two other officials 'have' a perca / perka, but theirs is different: instead of the adjective arsmatia, the word that describes this different kind of perca / perka is ponisiater / puniçate at VIb 51 / Ib 15. This word is apparently related to Latin püniceus, which can be translated as 'dyed purple'. ${ }^{15}$ At Ib 15, we see that two officials called prinuvatu must accompany the Adfertor, and they are to 'have' (habetutu) perkaf ... puniçate. Likewise at VIb 51, shown in sections $F d$ and $F e$ above, two prinuatur must accompany the Adfertor ( $F d$ ), and they are to 'have' (habituto) perca ... ponisiater ( $F e$ ). By contrast, as we already saw in section $F b$ at VIb 50, the Adfertor himself officially 'has' (habiest) the perca arsmatia.

\$17. The periphrasis designating the Adfertor as poe perca arsmatiam habiest 'the one who has [habiest] the perca arsmatia' is restricted in the Iguvine Tables to those parts of the overall text that are written in the Latin alphabet (besides the attestation in section $\mathrm{Fb}$ at $\mathrm{VIb} 50$, we see the phrase also at VIb 53, 63; VIIa 46, 51). From the other parts written in the Umbrian alphabet, however, we can verify that the arffertur is the same authorized person who is described as the one 'who has the perca arsmatia' in the part written in the Latin alphabet. In the part written in the Umbrian alphabet (Ib 41-42), it is the arrfertur who drives a sacrificial heifer while the two prinuvatu drive two other heifers; in the part written in the Latin

\footnotetext{
${ }^{15}$ GM 167.
} 
alphabet (VIIa 51), the sacrificial heifers are driven by poe perca arsmatiam habiest 'the one who has the perca arsmatia' and by the prinuatur.

\$18. In the parallel wordings that I have shown in the left-hand and right-hand columns taken from Tablets VIb and $\mathrm{Ib}$ respectively, the periphrasis in section $\mathrm{Fb}$ with reference to the Adfertor as poe perca arsmatiam habiest 'the one who has the perca arsmatia' in the Latin alphabet version $(A-H)$ cannot be contrasted directly with a counterpart in the Umbrian alphabet version $(\underline{A-H})$, since in one case the Adfertor is instructed in the grammatical third person $(\mathrm{A}-\mathrm{H})$ whereas in the other case he is instructed in the second person $(\underline{\mathrm{A}-\mathrm{H}})$. There is, however, a direct contrast in the wordings where we see references to the container of the fire to be carried by the Adfertor. The version $A-H$, which avoids referring to the chief sacrificer by his title, as Adfertor, also avoids referring to the sacred container, ahti, which is the equivalent of Latin focus in the sense of a 'fire container' or 'movable fireplace'. As we can see in the lefthand column, section $E$ has pir entendu 'he shall place fire' while the corresponding section $\underline{E}$ in the right-hand column has enumek pir ahtimem ententu 'then place fire [pir] in the ahti'. So the version written in the Latin alphabet avoids the mention of an ahti-which is how we would expect the word to be spelled in this alphabet.

\$19. I highlight an additional case of avoidance: in section $\mathrm{Fa}$, we read pufe pir entelust 'where the fire [pir] is placed', which is a periphrasis for the expected word ahti. Avoiding a direct statement, such as *'when the ahti is brought to the sacrifice', the language of section $F a$ says instead: pone esonome ferar pufe pir entelust 'when that in which he has placed the fire [pir] is carried [ferar] to the sacrifice'. By contrast we do see a direct statement in the wording that corresponds to section $F a$ in section $\underline{F}$, written in the native Umbrian dialect: there we read pune pir entelus ahtimem 'when you have placed the fire [pir] in the ahti'. 
\$20. In the version written in the Latin alphabet, which is newer by comparison with the version written in the native Umbrian alphabet, specific words dealing with the central authorized person and the central authorized object involved in the ritual are treated with special caution. That is to say, the newer version is more circumspect than the older version written in the native Umbrian alphabet. In my previous work on the periphrastic references to both the central authorized person and the central authorized object involved in the newer version, I described this sense of circumspection by applying the anthropological term tabu, also spelled as taboo. ${ }^{16}$

\$21. Besides being more circumspect, the instructions in the newer version $A-H$ are also in many ways more precise as well as more detailed than the instructions in the older version A$\underline{H}$. Granted, greater precision in the newer version may mean that the practitioners of the ritual have become increasingly less certain, with the passage of time, about the right way of doing things, but, the point is, the greatest care is taken about exactly that, doing things right. A striking example is the formulation in section $D b$, where it is specified that the sacrificer must place the garment called the cringatro on his right shoulder. In section $\underline{D}$, by contrast, it had sufficed to prescribe for the sacrificer that he must 'have' (hatu) the krenkatrum. Presumably, the stark prescription of the formula in section $\underline{D}$ was enough of a reminder about what to do next. Not so in section $D a$ : here the formulation does more than simply prescribe that the sacrificer must 'have' (hatu) the cringatro. Further specification has to follow in section $D b$ about what to do with the cringatro, that is, to put it on the right shoulder, and this detail is followed by a related detail concerning the same right shoulder: as we read further in section $F c$, the sacrificer must carry on his right shoulder something called an aso.

\footnotetext{
${ }^{16}$ GM 167, following Poultney 1959:271.
} 
\$22. I have already highlighted this something called the aso in section $F c$, but I have not yet attempted to formulate what this word means. The meaning, I argue, can be linked with two facts:

(1) The sacrificer, who is the Adfertor, had placed fire into a vessel, as we see in sections $E$ / $\underline{E}, F a / \underline{F}$.

(2) This vessel containing fire 'is carried to the sacrifice', esonome ferar, as we see in section $\mathrm{Fa}$. Here I highlight the use of the Umbrian verb ferar, equivalent of the Latin verb ferō 'carry': to say it in Umbrian, as we read here in section $F a$, pone esonome ferar pufe pir entelust 'when that in which he has placed the fire [pir] is carried [ferar] to the sacrifice'. Further, when the vessel containing fire is 'carried', ferar, to the sacrifice, as mentioned in section $F a$, the one who actually 'carries' this container must be the Adfertor himself, as mentioned in section $F b$, where the idea of 'carrying' the container is expressed by way of the Umbrian equivalent of Latin ferō 'carry': to say it in Umbrian, as we read here in section $F b$, ere fertu poe perca arsmatiam habiest 'he shall carry [fertu] it, the one who has the perca arsmatia'. So, the person who places the fire into the vessel is the same person who carries to the sacrifice this vessel that now contains the fire to be used for the sacrifice.

\$23. Accordingly, I argue that the thing called the aso, which the Adfertor must carry in section $F b$, is the same thing as the ahti that is mentioned overtly in section E. It is into this ahti that the Adfertor must place the fire that he must carry to the place of sacrifice.

§24. The ahti that is mentioned in section E must have been some kind of a portable bronze fire-container, that is, a brazier, and I think it may have had holes for the insertion of a wooden 
shaft for carrying it. ${ }^{17}$ In any case, whatever the shape of such a brazier may have been, we may compare the brazen cribrum or 'sieve' used by the Vestal Virgins as a movable fireplace, described as follows:

ignis Vestae si quando interstinctus esset, virgines verberibus adficiebantur a pontifice, quibus mos erat tabulam felicis materiae tamdiu terebrare, quousque exceptum ignem cribro aenea virgo in aedem ferret

Whenever the fire [ignis] of Vesta was interrupted, the Virgins were beaten by the pontifex; they [= the Virgins] had a custom of boring a board [tabula] of fêlix māteria until a fire [ignis] would take and, once it took, a Virgin carried [= verb ferō] it to the sanctuary inside a brazen cribrum.

Paulus ex Festo 94 ed. Lindsay ${ }^{18}$

\$25. We may compare the usage of tabula 'board' here with the following instruction in the description of another ritual in the Iguvine Tables, IIb 12: tafle e pir fertu 'carry [fertu] the fire [pir] to that place on a tafla', where tafla is the equivalent of Latin tabula and fertu is the equivalent of Latin fertō, third-person imperative of the verb ferō. In the case of the Roman ritual, the tabula is the surface for the kindling of the fire, while the cribrum is the container for carrying it. By contrast, in the Umbrian ritual recorded at IIb 12, the equivalent of the tabula is used both for the kindling of the fire and for the subsequent carrying of the fire. As for the Umbrian ritual that we are currently considering, as described in the parallel columns $A-H$ and

\footnotetext{
${ }^{17}$ I propose that such a brazier looked like the "fire-basket" (eighth century BCE) published by A. M. Snodgrass (1996:592-593, vol. III, Fig. 177; vol. IV, pl. 290), who says: "Clearly it was meant to hold some loose material, in pieces that were big enough not to fall through between the struts placed some $3 \mathrm{~cm}$ apart. It is suggested that the material was burning charcoal or other combustible materials.... [T] he inferred presence of a substantial wooden shaft would enable this material to be held at more than arm's length."

${ }^{18}$ GM 169. See also Weiss 105n22, with further bibliography.
} 
$\underline{\mathrm{A}-\mathrm{H}}$, I suggest that an equivalent of the tabula may have been used for the original kindling of the fire while a separate container is now being used for actually carrying the fire.

\$26. In the Iguvine Tables, we have seen that the text written in the Latin alphabet studiously avoids the use of the word ahti, written as ahti in the Umbrian alphabet, when referring to the container of the sacred fire $(E-F)$. I argue that this same text resorts to a synonym of ahti, which is the form aso, in section Fc at VIb 50: erihont aso destre onse fertu 'the same [= the Adfertor] shall carry [fertu] the aso on his right shoulder'.

\$27. In arguing that aso is a synonym of ahti, I take into consideration the syntax of sections $F a$ through $F c$ of the newer version. Because there is a specific mention of the right shoulder in section $F c$, something else must now also be mentioned. This something had not been directly mentioned by name in section $\mathrm{Fa}$, where we saw the periphrasis pufe pir entelust 'that in which he has placed the fire [pir]'. But this something must now be mentioned again, and this time it is done not by way of periphrasis but rather by way of using an equivalent word referring to the container for the sacred fire. This something in section $F c$ is the aso.

\$28. The Umbrian word aso, I argue, is not part of the sacral vocabulary used in the Iguvine Tables, and it is for this reason that it could be written out in the taboo-conscious ritual instructions of VIb 48-53. By contrast, ahti was very much part of the sacral vocabulary, and that is why it is not mentioned at all in section $E$ and is mentioned only indirectly, by periphrasis, in section $F a$.

\$29. As for the etymology of aso, I propose that it is a second-declension noun corresponding to the first-declension noun asa. Just as Umbrian asa 'altar', as we see this word used at IT IIa 38 and elsewhere, can be reconstructed as *assā, so also aso, as we see this word used in Fc at IT VIb 50, can be reconstructed as *asso- . In my previous work, I have argued that 
Umbrian aso is cognate with Hittite hašša-, which means 'fireplace, hearth', as also with Umbrian asa / asa and with Latin āra, both of which words mean 'altar'. ${ }^{19}$

\$30. I also propose that the Hittite word hašša- 'fireplace, hearth' was borrowed into Greek

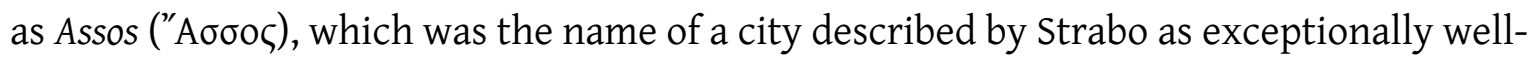
fortified and situated on steep rocky heights overlooking the sea in the Aeolic region of the Troad (13.1.51 C606, 13.1.57-58 C610, 15.3.22 C735; ${ }^{20}$ see also Pausanias 6.4.9). ${ }^{21}$

\$31. An objection has been made concerning my interpretation of aso as a synonym of ahti. If aso is really a synonym of ahti in the version of the Iguvine text written in the Latin alphabet, and if it is not a taboo word like ahti, then why is aso not used consistently instead of a periphrasis? $?^{22}$ And, if there was a synonym available, why would there be even any need for a periphrasis of ahti? In other words, if aso is really a synonym of ahti, why not use aso everywhere and thus avoid the periphrasis $?^{23}$ In terms of my argument, however, there is no reason for avoiding the periphrasis, which is a marked way of referring to the sacred container of the sacred fire, just as the word ahti itself is a marked way of referring to this container. Opacity of reference is a form of markedness. ${ }^{24}$ As for aso, it is an unmarked or "default" way of referring to the sacred container, and its single occurrence is situated in a context where the

\footnotetext{
${ }^{19}$ GM 151-155, 170-174.

${ }^{20}$ I note with interest the word Aioleus 'Aeolian' used in describing a man from Assos in the epigraphical evidence

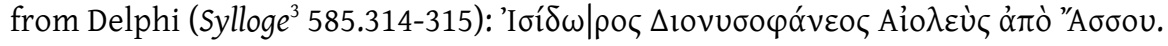

${ }^{21}$ In the scholia for Dionysius Periegetes, Orbis descriptio 850, it is said that Mopsos founded a city in Cilicia, and

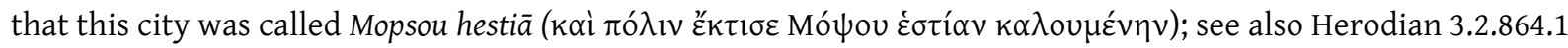

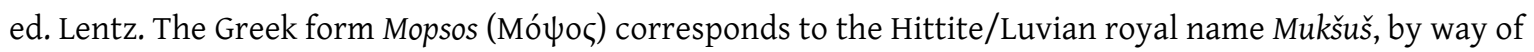
Phoenician, as we see in a Phoenician/Luvian bilingual inscription that descibes, in Phoenician, the eighthcentury king Urikki as a descendant of $m p \check{s}$; then, in Luvian, he is described as a descendant of mukšuš. See Bremmer 2008:142, citing the text published in Tekoglu and Lemaire 2000 and Lanfranchi 2005.

${ }^{22}$ Weiss 2010:152-153.

${ }^{23}$ Again, Weiss 2010:152-153.

${ }^{24}$ I use here the terms marked and unmarked along the lines formulated by Jakobson (especially 1957); details in Nagy 1990a Introduction §§12-16.
} 
marked way of referring to the container, by way of periphrasis, has already been used. In this single context, then, aso is used simply to avoid a repetition of the periphrasis, not for the sole purpose of avoiding the use of ahti itself.

§32. This is not to say that aso is a non-sacred word by virtue of the fact that ahti is sacred in a given historical context. It is only to say that aso, unlike ahti, is not marked for sacral usage in this particular context. There is no reason to rule out the existence of a sacral usage of aso at other times or in other places during the history and prehistory of the Umbrian language. A similar point can be made about the absence of a cognate of Latin ignis in attested Umbrian and Oscan. Such a word may have existed in contexts that are no longer attested. That possibility is reinforced if the reverse situation is true, that is, if I am right in seeing the cognate of Oscan and Umbrian pir in the pür- of Latin pürgō, despite the absence of the simplex noun * pūr 'fire' in attested Latin.

\section{Bibliography}

Bremmer, J. N. 2008. Greek religion and culture, the Bible, and the ancient Near East. Jerusalem Studies in Religion and Culture 8. Leiden.

Jakobson, R. 1957. "Shifters, Verbal Categories, and the Russian Verb." Reprinted in Jakobson 1984:41-58.

Jakobson, R. 1984. Russian and Slavic Grammar: Studies 1931-1981, edited by M. Halle and L. R. Waugh. The Hague.

Lanfranchi, G. 2005. "The Luwian-Phoenician Bilingual of Çineköy and the Annexation of Cilicia to the Assyrian Empire." Von Sumer bis Homer: Festschrift M. Schretter (ed. R. Rollinger) 481-496.

Nagy, G. 1974. "Six Studies of Sacral Vocabulary Relating to the Fireplace." Harvard Studies in Classical Philology 78:71-106.

Nagy, G. 1990a. Pindar's Homer: The Lyric Possession of an Epic Past. Baltimore. http://chs.harvard.edu/CHS/article/display/5283 
Nagy, G. 1990b. Greek Mythology and Poetics. Ithaca NY. Abbreviated as GM. http://chs.harvard.edu/CHS/article/display/5577

Nagy, G. 2007. "The fire ritual of the Iguvine Tables: Facing a central problem in the study of ritual language." Classical World 100:151-157.

Poultney, J. W. 1959. The Bronze Tables of Iguvium. Philological Monographs of the American Philological Association no. 18. Baltimore. https://archive.org/stream/bronzetablesofig00poul\#page/n19/mode/2up

Snodgrass, A. M. 1996. "Fire Baskets." Knossos: The North Cemetery II (ed. H. W. Catling and J. N. Coldstream) 592-593. London.

Tekoglu, R., and Lemaire, A. 2000. "La bilingue royale louvito-phénicienne de Çineköy."Comptes rendus des séances de l'Académie des inscriptions et belles-lettres 2000:961-1007.

Thurneysen, R. 1912-1913. “Zur Wortschöpfung im Lateinischen.” Indogermanische Forschungen 31:276-281.

Weiss, M. 2010. Language and Ritual in Sabellic Italy: The Ritual Complex of the Third and the Fourth Tabulae Iguvinae. Leiden and Boston. 